\title{
A STUDY OF SPEECH ACT BETWEEN SELLER AND BUYERS IN 'SINAGA SHOP'
}

\author{
Hilman Pardede ${ }^{* 1}$, Herman ${ }^{* 2}$ \\ hilmanpardede@yahoo.com ${ }^{* 1}$, herman@uhn.ac.id ${ }^{* 2}$ \\ English Education Department ${ }^{1,2}$, University of HKBP Nommensen, Medan, Indonesia
}

\begin{abstract}
This research is aimed to investigate the speech act between seller and buyers in 'Sinaga Shop'at Jalan Melanthon Siregar Pematangsiantar. Speech act is related to utterances. Communication can be said successful if the speech act between speaker and listener are good in daily life. The transaction in the market between seller and buyer is also inevitable. Therefore, the problem of this study is: "What kinds of speech act verbs do the sellers and buyers use in 'SINAGA SHOP' Jalan Melanthon Siregar Pematangsiantar in their daily conversational transaction? To answer the problem above, the researchers follow some theories that related with the problem, they are speech act theory by Austin (1962) and Searle (1985). Descriptive qualitative approach was conducted. Participants of this study are seller and buyers at "SINAGA SHOP". They are female and male. Context of the study is the utterances of seller and buyers in "SINAGA SHOP". After analyzing the data, the researchers found that there were some verbs that the seller and the buyer use in their daily transactional conversation, they are: Representative include suggest, report, state, inform, complain. Directive include ask, request, order. Expressive include apologize, thank, pardon. Commisive include offer and Declaratives include sentencing.
\end{abstract}

Keywords: illocutionary act, pragmatics, speech act, utterance

DOI: https://doi.org/10.31943/wej.v4i1.87

\section{INTRODUCTION}

According to Cruse (2000) in Pardede, Herman and Pratiwi (2019, p.1), language is use to communicate about things, happenings, and states of affairs in the world English is an international language, almost people from all over the country use English for their communication, that is why English very important language. Through language, the speaker can deliver their ideas to the listener. It means that the listener can catch the speaker ideas by language. The situation we called is speech act.

On the other hand, Communication needs speaker and listener to get the purpose and act. Act refers to locutionary act, illocutionary act, perlocutionary act. Communication depends on many factors. If people communicate they will speak 
around their culture, norms, and others. Herman, Murni, Sibarani and Saragih (2019 p.34) stated that language and culture are interconnected with one another. Culture means what to be habit in life and Norms means what to be ruled in life or a certain society.

Many people hope when they say something in a communication, the listener can understand what they say by their action or the way in delivering the information. In fact, many people are still not aware of the existence of the speech acts and how they create a proper action or replay with an appropriate action.

A communication process cannot be separated from speech act or speech event. Speech act is action which is shown by speech. In doing speech, speaker and audience are helped by surrounding situation and condition. The aspects of speech situation is devided into five criterion: addressers of addresses, the context of an utterance, the goal of an utterance, the utterance as a form of act or activity (a speech act) and, the utterance as a form of verbal act (Leech, 1983 p.15).

Yule (1996 p.47) as cited in Herman (2015 p.43) stated that when people speak a language, they will perform an action that performed via utterance (speech act). The Cooperative principle in communication consist of implicative and four maxims of conversation: maxim quantity, maxim quality, maxim relevance, maxim relevance, maxim manner. Beside that, Leech say that in direct locution terms to make polite because they increase degree of optionally and because the more its force tends to be (Leech, 1983 p. 108). It means indirect locution will make more polite utterance. So, it's clear that in communication process speaker and listener must consider to the cooperative principle and politeness principle so that the participants the best utterance from their speech act.

The usefulness of speech act is in illustrating the kinds of things we can do with words and identifying of some conventional utterance forms we use to perform specific actions (Yule, 1996 p.58),. However, we do need to look at more extended interaction to understand how those actions are carried out and interpreted with speech event.

In this research, the researchers are interested in conducting research about the usage of sellers' and buyers' speech act entitled "A Study of Speech Act between Sellers and Buyers in 'Sinaga Shop' at Jalan Melanthon Siregar Pematangsiantar"

\section{LITERATURE REVIEW \\ Pragmatics}

Yule (1996 p.3) states that pragmatics is concerned with the study of meaning as communicated by a speaker (or writer) and interpreted by a listener (or reader). Furthermore, Leech (1983) as cited in Pasaribu, Herman and Silalahi (2019 p.3) that pragmatic is a study of how utterance have meaning in situations It means that it has, consequently, more to do with analysis of what people mean by them. They include what we say, how to say it, our body language and whether it is appropriate to the given situation. (Slobin in Leech 1983 p.63) there are four principles of pragmatic, they are: 
1. Be humanly processible in on going time

2. Be clear

3. Be quick and easy

4. Be expressive

\section{Speech Act}

Hutajulu and Herman (2019 p.30) stated that Speech Acts is an utterance to explain how speaker use language to accomplish intended actions and how the hearers infer intended meaning from what is said. Communication is going on if there are speaker and listener. It is called speech community. Speech community is one all of whose members share at least a single speech variety and the norm of appropriate use. Speech community may be as small as single capacity.

Any interlocutors within a given speech community (or narrowly within a given speech network) must recognize the role relationship that exists between them at any norm and behavior upon which the existence of speech community depends.

In language, function goes hand and hand with structure. For structure of each sentences species the uses to which it can be put.

For example : Jone was hit by his brother.

In this sentence has a structure that is declarative sentence with "Jone" as subject and "was hit by his brother" as predicate. Because of its structure, it can be used to tell someone that Jone was hit by his brother or to ask the people to help Jone. For this reason, function is as important as a structure to the study of language.

Communication is the fundamental function of language. In this activity, there are three main elements. They are :

\section{A speaker \\ 2A hearer \\ 3.A signaling (for example : the language)}

Whenever they ask question, for example, they give listeners fails to appreciate this attention, they are judge as having "misunderstanding" even though in everything else about the utterances but how does each sentence convey its particular function? This question has been answered by Austin (1962 p.199) and Searle (1985 p.21), in speech act theory of them. In their view, every time speaker utters a sentence, they are attempting to accomplish something with the words. In this uttering sentences, speakers performs speech act.

\section{Notion of Speech Act}

To talk about speech act there are three notions that should be discussed, they are rule, preposition, and meaning (Searle, 1985 p.39)

Rule means knowing the meaning of words, it means by knowing the meaning of the words, we can use the words according to the context (Searle, 1985 p.40). In other words, the use of words, the use of words has rules that depends on the meaning and the context of the communication. There are two kinds or rules, namely: Regulative 
Rule and Constitutive Rule. Regulative rule tends to using of words that depends on the norm of society (Searle, 1985 p.41). Constitutive rule tends to the use of words out of norm of society (Searle, 1985 p.41). So, by knowing the rules for its use, we can find and know the meaning of the word.

Preposition means the comprehending between the subject and the predicate that is bound by a function (Searle, 1985 p.42).

Example:
a. will Fany leave the house
b. Fany leave the house
c. Fany, leave the house
d. would Fany leave the house
e. if $\mathrm{F}$ any leave the house, I will leave also.

All the sentences have the same topic and explanation but they have a different illocutionary act, why? Because they or the sentences have different function, A is a question, $\mathrm{B}$ is a assertion, $\mathrm{C}$ is request or order. $\mathrm{D}$ is an expression of a wish and the last, $\mathrm{E}$ is hypothetical of intention. Notice it is not said that the sentences express the proposition. It is not know the sentences could perform the acts, but should be know that in the utterances of the sentences the speaker express a proposition notice also. Proposition is not also assertion, or statement of that proposition. The proposition that fany will leave the house is shown in the all utterances, (la-e), but only in the sentence $b$ is the proposition asserted. An assertion as an illocutionary act, but a proposition as not an act all, although the act of expressing a proposition is a part of performing certain illocutionary acts.

\section{Austin's Theory}

When the communication happen, there are three things that are involved, they are speaker, hearer, and utterances. For instance, Mother : Vina, bring here the glass. In the conversation, the speaker is mother and the hearer is Vina. And the utterance is " Vina, bring here the glass".

According to Austin (1962 p.199), the utterances of the speaker can be divided into three meanings, they are Locutionary act, illocutionary act, and perlocutionary act (Austin in Leech, 1983:p. 199)

\section{Locutionary Act}

Locutionary act relates a topic with an explanation in an utterance. It is same with an explanation in an utterance. It is same relationship between subject and predicate. It is called a proposition act or performing the act of saying something. It can be also that Locutionary act is $\mathrm{S}$ says to $\mathrm{H}$ that $\mathrm{X}$.

Example: Merry: Hallo..

Hary: Hi..

It is locutionary act of this utterance is Merry greets Harry by saying "Hallo" 


\section{Illocutionary act}

Illocutionary act deals with the function of sentence, it could be asking information, greeting. Requesting, ordering, and many others. In other words, the illocutionary act is in uttering $X, S$ asserts that $P$.

For example : a. Buyer : How much?

b. Seller : Rp 3.500

c. Buyer : could you low it?

The illocutionary acts are :

a. Asking information

b. Giving information

c. And offering

\section{Perlocutionary Act}

Perlocutionary act is an effect that is bearded by the hearer according to the situation and context. In other words, it can be said perlocutionary act is by situation and context $\mathrm{X}, \mathrm{h}$, convinces $\mathrm{S}$ that $\mathrm{P}$.

For example : a. Jane : The weather is hot

b. Marry : I'll take you a cup of ice tea or I'll turn on the fan.

This example shows that by saying "the weather is hot" Jane wants Marry as addresse, to take him a cup of ice tea, and then Marry takes the tea because she understand what is the meaning of Jane utterances. "Taking a cup of ice tea" or "Turn on the fan" is a perlocutionary act. These are the effect of Marry utterance.

Now, if the locutionary, illocutionary, and perlocutionary act is related to the linguistics, in linguistic it can be said that the locution is prediction, illocutionary is sentence type, and perlocutionary is the meaning of sentence.

Example: a. The girl is diligent

b. The girl that is diligent

In this case, we find related between topic and explanation. As we know the topic is girl and the explanation is diligent.

c. She is the diligent girl

$\mathrm{d}$. The girl being diligent

e. A diligent girl

In these example (c, d, e), we find that the same prediction or locution that is to relate the topic "girl" and explanation is "diligent" compare with these sentences:

f. You are a diligent girl

g. Are you a diligent girl?

h. Be (you) a diligent girl!

From the example, we can seen the same locution between girl (you) and diligent, but they are different in illocution. Sentence (f) is a statement, sentence ( $\mathrm{g}$ ) is a question, and sentence (h) is command or instruction. 
In speech act theory, there is a new concept about meaning that has develop, that is the utterance effect to the hearer which is called "perlocution". Illcution is different from "perlocution". This statement can be received the following example:

i. How are you?

j. Who says?

These two utterance are different, "how are you"? is a question that function as greeting and "who says" is a question means to state unbelievable.

\section{Searle's Theory of Illocutionary Force}

Searle in Leech (1983 p.104) argues that there four major ways in which speech act they are: competitive, convivial, collaborative, conflictive.

An addition is Searle's purpose and it can be consist of the five points of categories the illocutionary act, they are:

1. Representative

Representative mean the speaker in uttering a representation converge his believe that some propositions are true.

Example: The sun shines on the east.

2. Directives

Directives mean the speaker attempt to get the listener to do something. Example: I hope you will some to my birthday party.

3. Expressive

Expressive means the speakers expresses his or her psychological state about something. Example: oh.... How big this church.

4. Commisive

Commisive mean the speaker admit himself to some future course of actions. Example: I promise, I will love you until the end of the time.

5. Declaratives

Declaratives mean when the speaker utters declarative, his word brings a new state of affairs. In other words, this declaratives is called felicity condition. Example: A priest says to a bride and bridegroom " I pronounce you to be wife and husband"

\section{Speech Act Meaning}

In conversation, every speaker operates a given set of language function to expose the language function. The writer uses Austin and Searle theory in order to expose the locutionary, illocutionary, and perlocutionary act. Every speech act has a certain value that influence the relationship among participants and the of communication.

Example :

a. Buyer: Wortel brapa inang? ( how much the carrot man ?)

b. Seller: Dua stengah ( two thousands and five hundred rupiah)

The sentences which is spoken by Buyer and Seller above can analyzed based on locutionary, illocutionary, and perlocutionary act as follows. 
Locutionary : Buyer ask to seller "Wortel brapa inang"?

Illocutionary : Seller gives information to Buyer "Dua stengah"

Perlocutionary : Buyer asks the price of carrot.

\section{Cooperative Principle}

One of basic principle that usually used as frame of reference is Grice. Grice (1975 p.308) categories four classification of speech act into maxim quantity, maxim quality, maxim relevance, and maxim manner.

Example :

a. Seller : cari apa eda? (What are you looking madam?)

b. Buyer : berapa bawang? (how much is onion?)

These utterances can be analyzed as follows :

Quantity : Seller gives order to the buyer as information as is what is she wanted.

Quality : the seller believes that the buyer is looking a thing that she want.

Relevant : The topic which is talked by the seller and buyer is relevance.

Manner : The seller and buyer use a sentence which is easy to understand.

\section{RESEARCH METHOD}

This research used the methodology of descriptive qualitative approach. According to Ary (2010 p.29), qualitative researchers seek to understand a phenomenon by focusing on the total picture rather than breaking it down into variables. Participants of the research were seller and buyers at "SINAGA SHOP" Jalan Melanthon Siregar Pematangsiantar. They were female and male. The seller was Mrs. Sinaga, 33 years old. The buyers were women and housewife children and also man in Jalan Melanthon Siregar Pematangsiantar. They were chosen randomly by the researcher since there was a transaction done. In this study, the researchers followed some steps in order to collect the data, they are:

1. Acquainting to the owner of the shop.

2. Observing the utterances of seller and buyers in "SINAGA SHOP" Jalan Melanthon Siregar Pematangsiantar.

3. Recording the utterances of seller and buyers when they are doing transaction.

4. Transcribing the Indonesian script of conversation between seller and buyers.

5. Taking note from the data. There were some verbs in the conversation that would be analyzed.

To analyze the data, the researchers use descriptive qualitative to analyze data. According to Sugiyono (2008 p. 245), activities to analyze data in descriptive qualitative research can cover data reduction, data display, and conclusion drawing/verification. Based on those statements, the researchers divides the activity in analyzing data into some steps, they were: 
1. Listening carefully and repeatedly to the conversation between seller and buyers while doing transaction.

2. Writing the English script of the conversation record between seller and buyers.

3. Analyzing it by using theory of Searle, and theory of Austin.

4. Interpreting the meaning of utterance from seller and buyers by using theory of Austin, Searle.

5. Finding the speech act verb used between sellers and buyers.

\section{FINDING AND DISCUSSION \\ Theory by Austin \\ Data 1: \\ 14:19 AM \\ Rustina \\ $10^{\text {th }}$}

Penjual : mau beli apa kau dek?(what do you want to buy sister?)

Pembeli: Rokok surya.( "Surya" cigarette.

Penjual: Rokok surya? Berapa sama mu?( Seller: cigarette? How many cigarette do you want?

Pembeli: dua batang.( two steam)

Penjual: Tunggu ya dek(.Wait a minute please)

Pembeli: ini satu ya kak(.And also this one sister)

Penjual :oh.biar pas 3.000 ya. Udah kau kasi uang mu?( oh, so it will be pass three thousands rupiahs. Have you given your money?)

Pembeli: ini kak. ( here my money)

Penjual: 5.000 uang mu ya. 2 kasi ya. Kembali kan 2.000. Makasi ya. ( Your money five thousands. Give her two steam cigarette and change her two thousands rupiah, Thank you)

The conversation can be analyzed by Austin's theory:

\section{Seller: what do you want to buy sister?}

Locutionary act of this utterance is seller ask to the buyer by saying simple question that is "mau beli apa kau dek?" (what do you want to buy sister?).

Illocutionary act of this utterance is ordering information. It means, the seller wants to know, what are the buyer looking for.

Perlocutionary act of this utterance is seller wants the buyer give her information about what things that she looking for.

Buyer: "Surya" cigarette.

Locutionary act of this utterance is the buyer says "Surya" cigarette. 
Illocutionary act of this utterance is giving information. It means, the buyer wants to buy cigarette.

Perlocutionary act of this utterance is the buyer wants that the seller give what the buyer wants.

\section{Seller: cigarette? How many cigarette do you want?}

Locutionary act of this utterance is seller ask to the buyer by saying a simple question that is "How many cigarette do you want?"

Illocutionary act of this utterance is ordering information. It means, the seller wants to know, how many cigarette that she want.

Perlocutionary act of this utterance is seller wants the buyer give her information about how many cigarette that she wants to buy.

\section{Buyer: two steam.}

Locutionary act of this utterance is the buyer say simple statement that is "two steam".

Illocutionary act of this utterance is giving information. It means that the buyer inform how many steam cigarette that she needed.

Perlocutionary act of this utterance is the buyer wanted that the seller gives her two steam cigarette.

\section{Seller: Wait a minute please.}

Locutionary act of this utterance is the seller says "wait a minute please".

Illocutionary act of this utterance is the seller wants the buyer wait for a minute.

Perlocutionary act of this utterance is the seller need an act of the buyer, does she wait or not.

Buyer: And also this one sister.

Locutionary act of this utterance is the buyer says "and also this one sister"

Illocutionary act of this utterance is the buyer inform what she needed again.

Perlocutionary act of this utterance is the buyer needs what the seller act after she said "and also this one sister".

Seller: oh, so it will be pass three thousands rupiahs. Have you given your money?

Locutionary act of this utterance is the seller ask to the buyer "have you given your money"?

Illocutionary act of this utterance is the seller inform how much that she will be paid. Perlocutionary act of this utterance is the seller wants that the buyer give her money.

Buyer: here you are.

Locutionary act of this utterance is the buyer gives money to the seller by saying "here you are"

Illocutionary act of this utterance is effect of the seller utterance that say have you given your money?

Seller: Your money five thousands rupiahs. Give her two steam cigarette and change her two thousands rupiahs. Thank you. 
Wiralodra English Journal (WEJ)

Vol 4 No 1 Maret 2020

Locutionary act of this utterance is the seller close the conversation by saying your money five thousands rupiahs. Give her two steam cigarette and change her two thousands rupiahs and the last the seller saying thank you.

Illocutionary act of this utterance is the effect of the buyer's utterance that says "here you are" or giving money.

\section{Theory by Searle}

Table 1 The Illocutionary Verb Based on Theory by Searle

\begin{tabular}{|c|c|c|c|c|c|c|}
\hline \multirow{2}{*}{ NO } & \multirow{2}{*}{ Conversation } & \multicolumn{5}{|c|}{ Searly Illocutionary Verb } \\
\hline & & Representative & Directive & Expressive & Commisive & Declarative \\
\hline 1. & $\begin{array}{l}\text { Data } 1 \\
\text { 1.Buyers: is there } \\
\text { "tempe", (traditional } \\
\text { food in Indonesia made } \\
\text { by soybean) mom? } \\
\text { 2.Seller: has sould out } \\
\text { sister. You should buy } \\
\text { it early morning. } \\
\text { 3.Buyer: eeh .. I saw a } \\
\text { neighbor cook it. I } \\
\text { interest to cook it too. } \\
\text { Never mind sister. }\end{array}$ & $\begin{array}{l}\text { Inform and } \\
\text { Suggest } \\
\text { report }\end{array}$ & Ask & & & \\
\hline 2. & $\begin{array}{l}\text { Data } 2 \\
\text { 1.Buyer: where was I } \\
\text { looking the "kepok" } \\
\text { (one kinds of banana) } \\
\text { banana? } \\
\text { 2.Seller: It should be } \\
\text { better you buy it in } \\
\text { "Pasar Horas". But } \\
\text { there should be quite. } \\
\text { 3.Buyer: Yes of course. } \\
\text { My sister really want to } \\
\text { eat "kolak",(the } \\
\text { traditional food in } \\
\text { Indonesia made by } \\
\text { cassava and } \\
\text { banana).But she prefers } \\
\text { cassava. } \\
\text { 4.Sellers: If there is no } \\
\text { banana, it is not } \\
\text { delicious. }\end{array}$ & $\begin{array}{l}\text { Suggest } \\
\text { State } \\
\text { Complain }\end{array}$ & ask & & & \\
\hline
\end{tabular}




\begin{tabular}{|c|c|c|c|c|c|c|}
\hline \multirow{2}{*}{ NO } & \multirow{2}{*}{ Conversation } & \multicolumn{5}{|c|}{ Searly Illocutionary Verb } \\
\hline & & Representative & Directive & Expressive & Commisive & Declarative \\
\hline 3. & $\begin{array}{l}\text { Data } 3 \\
\text { 1.Buyer: are the } \\
\text { vegetables still fresh } \\
\text { mom? } \\
\text { 2.Seller: The } \\
\text { vegetables not fresh } \\
\text { anymore sister. } \\
\text { 3.Buyer: do you have } \\
\text { onion? } \\
\text { 4.Seller: I have little. } \\
\text { 5.Buyer: your onion } \\
\text { also is not good. Do } \\
\text { you have turmeric? } \\
\text { 6.Seller: It has sold out } \\
\text { sister. It left not the } \\
\text { good one. }\end{array}$ & $\begin{array}{l}\text { Inform } \\
\text { Complain } \\
\text { Inform }\end{array}$ & Ask & & & \\
\hline 4. & $\begin{array}{l}\text { Data } 4 \\
\text { 1.Buyer: do you have } \\
\text { the potatoes mom? } \\
\text { 2.Seller:It has sold out. } \\
\text { 3.Buyer: Ouch.. } \\
\text { 4.Seller: do you want } \\
\text { to take the catfish } \\
\text { sister? } \\
\text { 5.Buyer: No I do not } \\
\text { want it. }\end{array}$ & Inform & Ask & & . & \\
\hline 5. & $\begin{array}{l}\text { Data } 5 \\
\text { 1.Buyer: Sister, I } \\
\text { would like to buy one } \\
\text { "momogi". } \\
\text { 2.Seller: One? Take it } \\
\text { please. } \\
\text { 3.Buyer: it is used up. } \\
\text { 4.Seller: how about the } \\
\text { other? } \\
\text { 5.Buyer: Sausage } \\
\end{array}$ & $\begin{array}{l}\text { Inform } \\
\text { State } \\
\text { inform }\end{array}$ & Order & & & \\
\hline
\end{tabular}


Wiralodra English Journal (WEJ)

Vol 4 No 1 Maret 2020

\begin{tabular}{|c|c|c|c|c|c|c|}
\hline \multirow{2}{*}{ NO } & \multirow{2}{*}{ Conversation } & \multicolumn{5}{|c|}{ Searly Illocutionary Verb } \\
\hline & & Representative & Directive & Expressive & Commisive & Declarative \\
\hline & $\begin{array}{l}\text { 6.Seller: The one } \\
\text { sausage cost is one } \\
\text { thousand rupiahs. } \\
\text { 7.Buyer: I want to buy } \\
\text { it two pack. }\end{array}$ & & order & & & \\
\hline 6. & $\begin{array}{l}\text { Data } 6 \\
\text { 1.Buyer: Mom, could } \\
\text { you bring me leafy } \\
\text { vegetables tomorrow } \\
\text { please? } \\
\text { 2.Seller: Ok } \\
\text { 3.Buyer: Don't forget } \\
\text { it. } \\
\text { 4.Seller: Of course } \\
\text { sister, I will bring it } \\
\text { tomorrow. }\end{array}$ & & Request & & Promise & \\
\hline 7. & $\begin{array}{l}\text { Data } 7 \\
\text { 1.Buyer: How much is } \\
\text { it the one kilogram } \\
\text { sugar cost sister? } \\
\text { 2Seller: It cost is } \\
\text { twelve thousands } \\
\text { rupiahs. } \\
\text { 3.Buyer: One powder } \\
\text { tea please sister. How } \\
\text { much is it cost? } \\
\text { 4.Seller: four thousands } \\
\text { and five hundreds } \\
\text { rupiah. } \\
\text { 5.Buyer: And all my } \\
\text { debt yesterday sister. } \\
\text { 6.Seller: Over all are } \\
\text { about twenty one } \\
\text { thousands and five } \\
\text { hundred rupiahs. } \\
\text { 7.Buyer: Oke sister. } \\
\text { (response) }\end{array}$ & $\begin{array}{l}\text { Inform } \\
\text { Inform } \\
\text { State } \\
\text { Inform }\end{array}$ & $\begin{array}{l}\text { Ask } \\
\\
\\
\text { Order } \\
\text { Ask }\end{array}$ & & & \\
\hline
\end{tabular}




\begin{tabular}{|c|c|c|c|c|c|c|}
\hline \multirow{2}{*}{ NO } & \multirow{2}{*}{ Conversation } & \multicolumn{5}{|c|}{ Searly Illocutionary Verb } \\
\hline & & Representative & Directive & Expressive & Commisive & Declarative \\
\hline 8. & $\begin{array}{l}\text { Data } 8 \\
\text { 1.Buyer: do you have } \\
\text { "kerupuk jangek"? } \\
\text { 2.Seller: Pardon me? } \\
\text { "Kerupuk jangek"? } \\
\text { 3.Buyer: Yes. } \\
\text { 4.Seller: Wait a } \\
\text { moment. } \\
\text { 5.Buyer: I want take it } \\
\text { two, which cost is five } \\
\text { hundreds rupiahs. } \\
\text { 6.Seller: Sorry, it has } \\
\text { sold out. How about } \\
\text { the other? } \\
\text { 7.Buyer: hmm. I don't } \\
\text { want. }\end{array}$ & State & $\begin{array}{r}\text { ask } \\
\text { Order } \\
\text { Ask }\end{array}$ & $\begin{array}{l}\text { Pardon } \\
\text { Apologize }\end{array}$ & & \\
\hline 9. & $\begin{array}{l}\text { Data } 9 \\
\text { 1.Buyer: Aunty, do you } \\
\text { have an ice cool pino? } \\
\text { 2.Seller: It is sold out. } \\
\text { 3.Seller: How about } \\
\text { cool x-tea? } \\
\text { 4.Seller: in the down of } \\
\text { freezer. } \\
\text { 5.Buyer: Momogi one } \\
\text { please, here my money. } \\
\text { Thank you. }\end{array}$ & $\begin{array}{l}\text { Inform } \\
\text { inform }\end{array}$ & Ask & Thank & offer & \\
\hline 10. & $\begin{array}{l}\text { Data } 10 \\
\text { 1.Seller: What do you } \\
\text { want to buy? } \\
\text { It is five hundreds } \\
\text { rupiahs Any other? } \\
\text { 2.Buyer: (directly give } \\
\text { his money to the seller) } \\
\text { 3.Seller: Thank you. }\end{array}$ & & ask & . & & \\
\hline
\end{tabular}


Wiralodra English Journal (WEJ)

Vol 4 No 1 Maret 2020

\begin{tabular}{|c|c|c|c|c|c|c|}
\hline \multirow{2}{*}{ NO } & \multirow{2}{*}{ Conversation } & \multicolumn{5}{|c|}{ Searly Illocutionary Verb } \\
\hline & & Representative & Directive & Expressive & Commisive & Declarative \\
\hline 11. & $\begin{array}{l}\text { Data 11 } \\
\text { 1.Buyer: do you have } \\
\text { "kerupuk jangek"? } \\
\text { 2.Seller: Pardon me? } \\
\text { "Kerupuk jangek"? } \\
\text { 3.Buyer: Yes. } \\
\text { 4.Seller: Wait a } \\
\text { moment. } \\
\text { 5.Buyer: I want take it } \\
\text { two, which cost is five } \\
\text { hundreds rupiahs. } \\
\text { 6.Seller: Sorry, it has } \\
\text { sold out. How about } \\
\text { the other? } \\
\text { 7.Buyer: hmm. I don't } \\
\text { want (refuse) }\end{array}$ & State & ask & $\begin{array}{l}\text { Pardon } \\
\text { apologize }\end{array}$ & order & \\
\hline 12 & $\begin{array}{l}\text { Data 12 } \\
\text { 1.Buyer: where was I } \\
\text { looking the "kepok" } \\
\text { (one kinds of banana) } \\
\text { banana? } \\
\text { 2.Seller: It should be } \\
\text { better you buy it in } \\
\text { "Pasar Horas". But } \\
\text { there should be quite. } \\
\text { 3.Buyer: Yes of course. } \\
\text { My sister really want to } \\
\text { eat "kolak",(the } \\
\text { traditional food in } \\
\text { Indonesia made by } \\
\text { cassava and banana). } \\
\text { But she prefers } \\
\text { cassava. } \\
\text { 4.Sellers: If there is no } \\
\text { banana, it is not } \\
\text { delicious. (response) } \\
\text { 5.Buyers: Yes of } \\
\text { course sister. She is }\end{array}$ & $\begin{array}{l}\text { Suggest } \\
\text { State }\end{array}$ & ask & & & entencing \\
\hline
\end{tabular}




\begin{tabular}{|c|c|c|c|c|c|c|}
\hline \multirow{2}{*}{ NO } & \multirow{2}{*}{ Conversation } & \multicolumn{5}{|c|}{ Searly Illocutionary Verb } \\
\hline & & Representative & Directive & Expressive & Commisive & Declarative \\
\hline & $\begin{array}{l}\text { cravings anymore. She } \\
\text { often told me to cook } \\
\text { "kolak" early. She told } \\
\text { also she will be hard to } \\
\text { born if she did not eat } \\
\text { "kolak". } \\
\text { 6.Seller: } \\
\text { Wow. } \\
\text { You must go the } \\
\text { market to buy it now. } \\
\text { 7.Buyer: Yes sister. I } \\
\text { go to the market to buy } \\
\text { it. It is so difficult to } \\
\text { face the pregnant } \\
\text { woman. }\end{array}$ & $\begin{array}{l}\text { Suggest } \\
\text { State }\end{array}$ & & & & \\
\hline
\end{tabular}

After considering the data analysis of the conversation, the researchers conclude findings as following: The speech act that the seller and the buyer use in their daily conversation based on illocutionary force by Searle, areRepresentative include (suggest, report, state, inform, complain), Directive include (ask, request, order), Expressive include (apologize, thank, pardon), Commisive include (offer) andDeclaratives include (sentencing).

When the researcher did the data analysis, there were some other findings that the researchers would like to discuss. While doing this research, the researchers found some other speech act aspect besides the speech act verb by Searle. It is shown by the conversation:

Marvel (6 ${ }^{\text {th }}$ years old)

Pembeli: kak,beli momogi satu. ( Sister, I want to buy one "momogi")

Penjual: satu? Ambil lah ambil.( One? Take it please)

Pembeli: habis.( it is used up)

Penjual: yang lain lah ambil. ( how about the other?)

Pembeli: sosis.( Sausage)

Penjual: sosis seribu satu ya.( The one sausage cost is one thousand rupiahs)

Pembeli: aku mau beli dua.( I want to buy it two pack)

Penjual: ia ambil lah.( Take it please)

Pembeli: baru satu lagi.( And I want to buy something)

Penjual: apa lagi? itu seribu satu ya dek.( any other? It is one thousand rupiah per pack)

Pembeli: ia.( yes) 
Wiralodra English Journal (WEJ)

Vol 4 No 1 Maret 2020

Penjual: makasi..( Thank you)

From the short conversation between the seller and buyers, the researchers found research beside of the speech act verb, like when the seller said "Thank you". To express say "thank you" after the seller and buyers did transaction, it was an expressing of politeness. But in the conversation, we did not see how the seller and the buyer how to start the conversation. It caused by culture of the seller and buyers. So, it will be better if the seller and buyers did greeting to start their conversation like in western culture.

\section{CONCLUSION}

Based on the data analysis and discussion which have been done in previous point above, the researchers conclude it will be better if the seller and buyer start the conversation with opening like to say "hello" and closing like to say "thank you". For English teacher, this research can be as a reference in teaching the students how to communicate while doing transaction and add the knowledge of verbs of transaction, especially in the era of industry 4.0. Hence, the researchers also want to suggest to teachers, specially, that how to have a good communication in teaching learning process in order to achieve the goals. And also teachers teach students how to communicate in a society to socialize with others. while doing transaction and add the knowledge of verbs of transaction.

\section{REFERENCES}

Ary, D. (2010). Introduction to Research in Education. Eight Edition, Canada: Wadsworth Cencage

Austin, J.L. (1962). How to do Things with words, Michigan: President and Fellows

Grice, H. P. (1975) 'Logic and conversation'. In P. Cole and J. Morgan (eds) Studies in Syntax and Semantics III: Speech Acts, New York: Academic Press, pp. 183-98

Herman. (2015). Illocutionary acts analysis of Chinese in Pematangsiantar. International Journal of Humanities and Social Science Invention. ANED.29.7722/0401202041048. Available at: http://www.ijhssi.org/papers/v4(12)/Version-2/E0401202041048.pdf

Herman, Murni, S.M., Sibarani, B., Saragih, A. (2019). Structures of representational metafunctions of the "Cheng Beng" ceremony in Pematangsiantar: A multimodal analysis. International Journal of Innovation, Creativity and Change. Volume 8, Issue 4, 2019. pp. 34-46 
Hutajulu, F. S. L. and Herman (2019). Analysis of Illocutionary Act in the Movie "You Are My Home" English Subtitle.Journal of English Educational Study. Volume 2 Issue 1 May 2019 Page 29-36. E-ISSN: 2655-0776. Available at: http://jurnal.stkippersada.ac.id/jurnal/index.php/JEES/article/view/371

Leech, G. (1983). The Principles of pragmatic. London: Longman

Pasaribu, S., Herman, and Silalahi, D.E. (2019). The speech act between teacher and students in teaching and learning process. Multidisciplinary European Academic Journal, Vol. 1, No. 1. Available at: https://syniutajournals.com/index.php/MEAJ/article/view/94/87

Pardede, H., Herman, and Pratiwi, W. (2019). An Analysis of Politeness Principle Maxims Found in Big Hero 6 Movie.European Exploratory Scientific Journal. Vol. $3, \quad$ No. 4. Available at: https://syniutajournals.com/index.php/EESJ/article/view/87/80

Searle, J.R. (1985).The philosophy of language. London: Oxford University Press

Sugiyono (2008). Metode penelitian kuantitatif kualitatif dan R\&D. Bandung: ALFABETA.

Tutuarima, Z., Nuraeningsih, and Rusiana. (2018). An analysis on speech act used in London Has Fallen Movie. Vision: Journal for Language and Foreign Language Learning, 2018. VOL.7, NO.2, 160-169.

Yule, G. (1996). Pragmatics. Oxford: University Press 